\title{
Ulrich Beck na hranici sociológie náboženstva a filozofie náboženstva
}

\author{
Ulrich Beck: Vlastní Bưh. \\ Mírotvorný a násilný potenciál náboženství \\ Praha, Karolinum 2018, 208 s.
}

Úvahy nemeckého sociológa Ulricha Becka o náboženstve, sú súčast́ou a príspevkom do vel’kého „rozhovoru“ o religiozite na začiatku 21. storočia. Jedným z klúčových Beckových zámerov bolo uvažovat” o fenoméne vytvorenia „vlastného Boha" v náboženskej oblasti a zamysliet́ sa zároveň nad mierotvorným a násilným aspektom či rozmerom, ktorý je prítomný v náboženstvách. Náboženstvo má tak dve „tváre“ - tolerantnú a násilnú. Kládol si otázku: ako je možné civilizovat’ globálny konfliktný potenciál medzi monoteistickými svetovými náboženstvami? Aj ked' toto sebacivilizovanie náboženstva nie je politickou záležitostou a výsledkom politického konania, predsa je nanajvýš dôležité z globálno-politického hladiska. Pokial' ide o „vlastného Boha“ (der eigene Gott), tento je - ako poznamenal Zygmunt Bauman v korešpondencii s Beckom - úplne novým druhom Boha - a DIY god. ${ }^{1}$ Nie je inštitucionálne vytvorený a propagovaný, ani prijatý, ale je to Boh individuálne chcený, ušitý na mieru, sledujúci logiku individuálnych záujmov a priorít [Bauman 2014: 74].

Beck vo svojich textoch prekračoval rámec sociológie náboženstva a formuloval otázky, ktoré môžu byt’ položené aj vo filozofii náboženstva. Jeho pozíciu „na hranici“ medzi sociológiou náboženstva a filozofiou náboženstva možno vidiet' prinajmenšom v dvoch smeroch. Prvým je formulovanie filozofických otázok a miestami i snaha na tieto otázky odpovedat'. Resp. už samotným formulovaním otázky predznačit' odpoved'. Druhým je presah do filozofie náboženstva, s reflektovaním a recepciou filozofických pozícií, riešení a konceptov. Odkazuje napr. na J. Habermasa, A. Schopenhauera, O. Marquarda, J. Locka, M. Foucaulta, a d’alších. Beckom skúmané pole religiozity je značne široké, sám nastoluje viac tém a formuluje viaceré otázky. V eseji upriamim pozornost' na miesta jeho sociologického prieniku k filozofii, na hranicu, kde sa uvedené disciplíny stretávajú, kde Beck ako sociológ formuluje otázky relevantné pre filozofiu náboženstva a taktiež kde si „zapožičiava“ či preberá filozofické stratégie.

Sociológovia si nesporne uvedomujú dôležitost' teoretických modelov či presnejšie konceptov vo vlastnom výskume a spracovaní empirických dát. Hovoria o nepostrádatel'nosti teórie v sociologickom bádaní, ,jemuž poskytuje ins-

1 Z anglického "do-it-yourself".

(C) Sociologický ústav AV ČR, v. v. i., Praha 2019 
piraci pro kladení podnětných sociologických otázek a formulaci nosných sociologických problémů a zároveň představuje cílový výstup, k němuž by empirický výzkum měl v principu směřovat" [Vido 2011: 1084]. Sú si vedomí, že sociológia náboženstva sa nezaobíde bez spolupráce s inými vednými odbormi, ktoré sa zaoberajú náboženstvom [Váně 2013]. Filozofia v tomto smere bola a ostáva sociológii nápomocná.

\section{Metodologická poznámka}

Na začiatok bude vhodné vymedzit prístup a diferenciu sociológie a filozofie náboženstva, kde ten istý predmet skúmania je "uchopený“ odlišným spôsobom. Nesporne je príliš riskantné a problematické zjednodušovat', no bolo by možné tvrdit', že podstatný a zásadný rozdiel medzi filozofiou a sociológiou náboženstva je, že filozofia sa zameriava na „vnútornú" stránku náboženstva, jeho jadro, základ, východisko, reálnoste či nereálnoste tohto základu (Boh, transcendentno, nadprirodzeno) a sociológia náboženstva upriamuje pozornost́ na jeho „vonkajšiu“" stránku, na prejavy, funkcie a úlohy náboženstva v spoločnosti. Obmedzuje sa na „lidskou dimenzi náboženských jevů a vztahů, aniž může vypovídat o jejich ,pravdivosti“" [Nešpor, Lužný 2007: 24]. Od toho sa odvíja kladenie otázok v oboch disciplínach. To pochopitel'ne neznamená, že filozofia náboženstva netematizuje vztáah náboženstva a spoločnosti a že sociológia náboženstva si nekladie otázky prekračujúce rámec empirického výskumu.

Klúčovým rozdielom sociológie náboženstva a filozofie náboženstva je teda kladenie či nekladenie otázky týkajúcej sa existencie transcendentna. Sociológia na rozdiel od niektorých typov filozofie náboženstva si túto otázku nekladie. Vo filozofii je táto otázka primárnou v tzv. filozofickej, resp. prirodzenej teológii a filozof sa pokúša o podanie dôkazu existencie Boha (transcendentného jestvujúcna, absolútna, prvej príčiny a pod.) a o vymedzenie jeho podstaty [Nešpor, Lužný 2007; Schaeffler 2003].

Ulrich Beck poznamenáva, že sociológovia vylučujú, že by náboženské javy mali byt' vysvetlované nábožensky a ich základným prístupom je metodologický sekularizmus, „, $\mathrm{v}$ souladu s nímž mají náboženské jevy primárně společenské př́činy a funkce“. Kladie si pritom z môjho pohladu zásadnú otázku, ked" sa pýta, či areligiozita a antireligiozita sociologického prístupu dokáže rozlúštił aj spoločenskú a politickú moc „,vlastného Boha“. Sociológia a náboženstvo sa majú k sebe ako oheň a voda [Beck 2018: 138]. Ak jeho myšlienky zovšeobecníme a rozvinieme, znamenalo by to, že sociológia by vnímala a interpretovala náboženstvo inak, ako chápe ono samo seba; je dokonca antireligiózna. A je možné - použijúc Beckovo prirovnanie - že v krajnom prípade by ho svojím prístupom „zahasila“ ako niečo nepodstatné a nevýznamné. Znamenalo by to, že náboženstvo by pre ňu bolo v konečnom dôsledku iba "dymom“ a "popolom“. Stratilo by živost', jas a silu prospešného ohňa. Stálo by na okraji sociologického záujmu. 
Sociológovia náboženstva samotní si tieto problémy uvedomujú a kladú si otázku, či dokážu relevantne zachytitł javy spájané s náboženstvom, vypovedat' o týchto skutočnostiach a pýtajú sa aj na formy legitimizácie predkladaných výpovedí. Tiež sa pýtajú, či náboženstvo skutočne zohráva nosnú úlohu pri integrovaní spoločnosti, alebo či je významné iba v individuálnom živote. Pokial' by platilo, že nie je konštitutívne v sociálnej sfére a nezohráva významnú úlohu vo svetovom dianí, sociológia náboženstva by mala marginálne postavenie [Váně 2010: 74, 80].

Nie som si istý, či úplne rozumiem Beckovmu konštatovaniu. Ak Beck tvrdí, že východiskom sociológa je metodický sekularizmus a náboženské javy majú "spoločenské príčiny“, nepriamo tým zastáva presvedčenie, že transcendentno nejestvuje. Z môjho pohladu teda nechápe sociológiu náboženstva ako disciplínu, ktorá si nekladie otázku o existencii transcendentna, nerozhoduje o ňom, ale ako disciplínu, ktorá existenciu transcendentna popiera. Rozdiel je neklást' si otázku o existencii transcendentna na jednej strane a na strane druhej zastávat' pozíciu sekularizmu, ktorý nadprirodzeno vylučuje, zbavuje náboženské jeho „,kúzla“, odmieta transcendentný rozmer náboženského. Ide o dva odlišné postoje, pričom sociológia náboženstva by v tomto prípade už nebola "neutrálna“. Preto by bolo z môjho pohladu dôslednejšie - považujem to za čisto pracovný "návrh“ - rozlíšit v sociológii náboženstva tri základné prístupy, resp. tri typy sociológie náboženstva: nenáboženskú, resp. antináboženskú, náboženskú a agnostickú sociológiu náboženstva. V prvom prípade sociológ apriori odmieta a popiera transcendentno, $\mathrm{v}$ druhom prípade transcendentno prijíma a $\mathrm{v}$ tretóom prípade o ňom nerozhoduje, nekladie si túto otázku.

Ďalší rozdiel sa týka pravdivosti jednotlivých náboženstiev, či hladania „pravého“ náboženstva. „,Sociologie náboženství si neklade otázku po pravdě, ale po hodnotě, jakou hraje náboženství v a pro společnost či jednotlivce.“ [Váně 2013] Na rozdiel od nej v dejinách filozofie môžeme nájst' autorov, ktorí si kládli otázku o pravdivosti jednotlivých náboženstiev (Porfýrios, Augustín, Akvinský, Kuzánsky). Arabský filozof Averroes považoval islam za ",pečat náboženstiev“", za absolútne dokonalé náboženstvo, ktoré má univerzálny charakter. Podla Nietzscheho je krestanstvo najväčším nepriatel'om l'udstva, pričom budhizmus je hodnotený pozitívne. V krestáanstve sa nedotýka ani morálka, ani náboženstvo skutočnosti. Budhizmus je pravdivejší a objektívnejší. Pochopitel'ne ide o prístupy patriace minulosti, no určitá tendencia "uprednostňovat" a špecifickým spôsobom považovat’ za univerzálne, ak už nie za ,,jediné pravé/pravdivé“, u niektorých filozofov ostala dodnes. Napr. taliansky filozof Gianni Vattimo sa domnieva, že v dnešnom svete nám jedinú šancu aby sme prežili ako lúdia, poskytuje krestáanské prikázanie lásky [Vattimo 2007: 57].

Sociológia náboženstva a filozofia náboženstva sa zhodujú v tom, že diferencujú sociológiu náboženstva a filozofiu náboženstva na jednej strane a náboženskú sociológiu a náboženskú filozofiu na strane druhej. Vedia, že predporozumenie, východisko a svetonázorové postoje sa premietajú do výsledkov ich 
„práce“. Rovnako si obe uvedomujú tažkost’ definovat” základný pojem „náboženstvo", teda sú si vedomé širokého rozsahu a viacvýznamovosti tohto pojmu, ako aj daalších základných pojmov.

\section{Formulovanie otázok: príklad postmodernej religiozity}

Jedným z príkladov, kde Beck formuluje otázky dôležité aj pre filozofiu náboženstva, sú miesta, na ktorých sa zaoberá postmodernou religiozitou. Postmoderný svet podl'a neho začína tam, kde náboženské a vedecké poznanie stratilo svoju nevinnost' a vzniká ich rovnoprávnost'. Beck chápe vedecké poznanie rovnako ako súčasný taliansky filozof Gianni Vattimo, na ktorého sa však neodvoláva. Vedecké poznanie je tiež interpretáciou sveta, interpretáciou, ktorá nedokáže poskytnút konečnú pravdu o realite. Náboženská postmoderna sa tak rozchádza s jedným zo základných princípov prvej, sekulárnej moderny, konkrétne s predstavou, že by objektívne poznanie o svete mala poskytovat jedine moderná veda. Stojíme pred relatívnostou vedeckého poznania a náboženskej viery [Beck 2018: 138].

Náboženská postmoderna vychádza podla Becka z toho, že sa nedá intelektuálne zdôvodnit a rozhodnút vol'ba medzi viacerými "pravdami“ a preto treba volit pragmatický prístup („„čo mi robí dobre“). Nielen pravda, ale aj dobro, krása a láska sú vecou osobného názoru. Jednotlivci si volia vlastnú duchovnú cestu, autentickost ich osobného hladania je pre nich dôležitejšia než prevzatie "právd“, ktoré zastávajú, ochraňujú a odovzdávajú tradičné náboženstvá.

Beck následne kladie otázky, ktoré sú z môjho pohladu podstatné aj pre súčasnú filozofiu náboženstva. „Dokáže eklektický př́stup k náboženské pluralitě sám o sobě nalézt své pevné dno? Nechybí snad konstrukcím „vlastního Boha“ vztah k "venku“" který teprve dodává úvahám o „vykoupení“ legitimitu? Nakolik může ono „vlastní“ na vlastním Bohu založit náboženskou závaznost, která toto „vlastní" vlastního Boha vyvažuje a neutralizuje? Co v procesu individualizace víry udržuje vědomí v bdělosti, aby základy "vlastní" religiozity mohly být získány a hájeny pouze ve veřejné politické výměně názorů s druhými? Jak se vyhnout případùm privatizace náboženství a jak se umožní a rozvinou veřejné formy náboženských praktik, které zaujmou společensky aktivní roli, a to jak sociálně, tak politicky, v boji proti nespravedlivé a sebe samu ohrožující civilizaci? Projevuje se snad v módní afinitě individualizace a esoteriky konstanta úhrnu náboženské energie, tedy to, že se vlastní život neobejde bez transcendentního vztažného rámce? Není tomu tak, že u postmoderní religiozity nejde ani tak o to, stát se náboženským, ani o to, patřit do nějakého náboženského společenství, ale o to, nalézt takovou skladbu náboženských praktik a symbolů, která nejlépe poslouží k dosažení vlastního štěstí, zdraví, cíle vlastního života?" [Beck 2018: 139]

Nepochybne sú Beckove otázky, opisy a analýzy postmodernej religiozity výstižné. Možno povedat' a dodat', že v náboženskej oblasti sa pevnou pôdou a ar-

bitrom stalo indivíduum samo, jeho myslenie, kreativita, iniciatíva. Začiatky sú 
značne viditel'né už u mladej generácie. Domnievam sa, že jednotlivec sa v danej situácii bude uberat' dvoma cestami. Prvá cesta je utvrdenie sa vo vlastnej vol'be, vo vlastnej pozícii, v spokojnosti s „vlastným Bohom“, s privátnou podobou religiozity. Postoj nedôvery voči inštitucionálnej forme náboženstva sa tu môže dalej prehlbovat. Druhá cesta je cestou prehodnotenia dosiahnutého stavu, jeho spochybnenie a hl'adanie pevnejšieho základu. Môžeme však predpokladat', že druhý prístup bude mat́ menej zástancov. Je náročnejší, vyžaduje väčšie úsilie, kritické myslenie a sebaformovanie, sebavzdelávanie.

Postmoderná religiozita a ani antimoderný fundamentalizmus nie sú vhodnou odpoved'ou na novú kozmopolitnú situáciu. Kozmopolitizmus vo svojom jadre podla Becka znamená prijat' inakosț druhých; nevyrovnáva, ani neruší všetky rozdiely, ale je zásadným znovunájdením a uznaním druhého. Odpovedou je religiozita druhej moderny, ktorá rešpektuje rozdielne základy viery jednotlivých náboženstiev, bez nutnosti náboženskej vojny či násilia. „Kozmopolitné“ znamená vidiet' svoje náboženstvo a kultúru očami druhého. Beck opät' formuluje d’alšiu otázku: „Jak by mohl tento ,kosmopolitní duch' světové společnosti doopravdy uspět a jak velké jsou realisticky jeho šance?“" [Beck 2018: 140, 2007; Köhler 2009]

\section{Recepcia filozofického konceptu: Habermas}

Habermasov značný vplyv na sociológiu dosvedčujú nielen konkrétne, samostatné štúdie, ale aj diela zamerané na explicitné demonštrovanie vplyvu nemeckého filozofa na sociologický výskum. Jednou z nich je publikácia Kritická teória Jürgena Habermasa v sociologickom výskume. Editor publikácie vo svojom príspevku konštatuje, že v sociologickej literatúre orientovanej na problematiku náboženstva sú odkazy na Habermasovo dielo pomerne zriedkavé, zväčša sa objavujú až po roku 1989 (Casanova, Herbert). Za zlomový rok Habermasovho uvažovania o náboženstve možno považovat' rok 2004, ked viedol rozhovor s kardinálom Ratzingerom, ktorý pokračoval aj v dalšom období. Okrem toho publikoval k problematike náboženstva d’alšie texty, pričom významnou je najmä prednáška Viera a poznanie z roku 2001, prednesená pri príležitosti udelenia Mierovej ceny Nemeckého knižného obchodu [Tížik 2013: 74-75; Habermas 2001, 2003].

Habermas zdôvodnil, prečo sa zaoberá tematikou viery a poznania (vedenia, Wissen). Podla jeho slov je to želanie mobilizovat' rozum voči defetizmu, ktorý pramení v ňom samom. S týmto rozumovým defetizmom sa postmetafyzické myslenie môže samo vysporiadat'. Profánny rozum ktorý nepodlahol defetizmu, rešpektuje jadro náboženstva, nezbavuje ho tohto jadra, pristupuje k náboženstvu s patričným uznaním a súčasne ostáva v odstupe voči nemu. Aký je dôvod takéhoto postoja rozumu voči náboženstvu? „Ví, že znesvěcení sakrálna začíná oněmi světovými náboženstvími, která odkouzlila magii, překonala mýtus, přeměnila obět a odhalila tajemství. Tak si může zachovávat odstup od náboženství, aniž by se uzavíral jeho perspektivě." [Habermas 2003: 123] 
Doplním krátko, že Habermas sa problematikou vztahu viery a rozumu (poznania) a tematikou defetizmu zaoberal aj v Revue de métaphysique et de morale, kde možno vidiet', ako jeho idey smerujú až ku Kantovi. Objasňuje tu aktuálny význam Kantovej filozofie náboženstva vôbec a tiež pre neho samého. Ťažiskom je myšlienka prisvojenia si sémantického dedičstva náboženského podania (tradície) bez toho, aby sa zotreli hranice medzi univerzom viery a poznania. Vo verejnom diskurze môže byt̆ filozofia v úlohe prekladatela podporujúceho morálnu, právnu a politickú zhodu. V tejto roli „interpreta“ dokáže prispiet’ k obnove senzibility, myšlienok a motívov, ktoré síce pochádzajú z iných (náboženských) zdrojov, no ostali by uzatvorené, pokial' by neboli privedené na svetlo verejného rozumu prostredníctvom práce filozofických pojmov [Habermas 2004: 481].

Prečo sa Beck obracia k Habermasovi? Odkazuje na neho v súvislosti s otázkou či problémom zcivilizovania svetových konfliktov, pričom rozlišuje pät modelov tohto zcivilizovania. Jedným z nich je model ústavného štátu neutrálneho k náboženstvám, ktorý nachádza u Habermasa. Podla nemeckého filozofa bol moderný ústavný štát vynájdený tiež preto, aby umožnil pokojný náboženský pluralizmus. Štát zaručuje a garantuje tolerantné spolunažívanie občanov rozdielnych vyznaní, ale aj vztáah veriacich a neveriacich, resp. štátu a náboženstva vôbec; konflikt náboženstiev je ústavno-právne regulovaný. Štát by v zásade nemal vylučovat' či odmietat’ hlas prichádzajúci zo strany náboženstva, svetská strana by si mala zachovat' určitý zmysel pre artikulačnú silu náboženských jazykov, ako sa Habermas vyslovil v spomenutej prednáške. Beck pripomína, že Habermas tu obhajuje aj Heglovu tézu, podla ktorej sú vel'ké náboženstvá súčastou Rozumu samého.

Za Habermasovou tézou stojí tiež koncept „postsekulárnej spoločnosti“. Ak sa z pohladu Becka sekularizmus absolutizuje, stáva sa slepým a robí nás slepými voči uznaniu iných duchovných tradícií, ich dejín, humanity, dôstojnosti. Na rozdiel od sekulárnej moderny je postsekulárna moderna otvorená a vnímavá ku kozmopolitnej spoločnosti. Sekulárna spoločnost́ sa preto musí stat́ postsekulárnou, čo znamená skeptickou, resp. kritickou a otvorenou zároveň k hlasom náboženstiev. Náboženský diskurz preto nie je vo verejnom priestore považovaný za porušenie pravidiel či narušenie neutrality, ale skôr za obohacujúci príspevok. Náboženstvo prispieva svojím vkladom do „spoločného“ a prináša to cenné z jeho obsahov, čo môže podporit” a "„̌̌ivit“" ludskost' a tolerantné spolunažívanie.

Beck sa nedomnieval, že Habermasov model regulácie náboženských konfliktov a netolerancie prostriedkami právneho štátu zostáva na úrovni, resp. v zajatí mikrooptiky národného štátu. Jeho predstava má globálny rozmer, nakol'ko univerzalistickú ideu ústavy vyväzuje $\mathrm{z}$ hraníc národného štátu; ide smerom k „,nadnárodným“, odštátneným „ústavám“, k ústave svetovej spoločnosti. Týmto ale vzniká problém, ako civilizovat́ náboženské konflikty v globálnom priestore, v kozmopolitnej konštelácii, mimo rámec donucovacej moci štátov. Jediným riešením je, že civilizovanie sa transformuje, posúva smerom k seba-civilizovaniu, 
ktoré je zverené náboženstvám samotným, čím sa na ne vytvára určitý tlak: mierové spolužitie už nezabezpečuje a nechráni "tretia“ nenáboženská strana (štát, zákon), ale oni sami. Beck však tvrdí, že Habermas vo svojich úvahách opomenul klúčový problém: ako by sa mohla - bez nestrannej usmerňujúcej inštancie - premenit" "exkluzívna a zanietená forma“, ktorou je monoteizmus, pri konfkliktnom strete s inými náboženstvami na formu vnútornej náboženskej tolerancie, uprednostňujúcej mierumilovnost? [Beck 2018: 157-161]

\section{Poznámky a otázky}

Z pohl'adu Ulricha Becka „vlastný Boh“ nie je jediným Bohom, ktorý riadi dejiny, je nositel'om spásy a oprávňuje či splnomocňuje netolerantné, násilné konanie svojich verných. Skôr sa tu uplatňuje princíp subjektívneho polyteizmu, ktorý však nemá nič spoločné s antickým polyteizmom a ani s misijným úsilím krestanstva integrovate do seba pôvodné náboženské tradície. Táto nová forma religiozity prekračuje náboženské hranice a má svojich prívržencov aj preto, že predstavuje „odpor proti institucionální neústupnosti“ [Beck 2018: 70].

V tejto forme viery môže vzniknút - s použitím trochu pozmeneného výrazu filozofa Oda Marquarda - subjektívne chcená a realizovaná „del'ba moci v absolútne“" ktorá je proti nároku na výlučnost', prítomnému v monoteistických náboženstvách. Jedná sa o príklad synkretickej tolerancie, viditel'nej a rozšírenej najmä v Ázii. Iba pripomeniem, že podla Marquarda je monoteizmus náboženská forma, ktorá nepripúšt́a žiadnu mnohost’ a neponecháva žiadny priestor pre rôznost'. Polyteizmus, resp. kozmoteizmus je prameňom rôznosti a vzájomnej tolerancie. Za vel'ký humánny princíp polyteizmu považoval Marquard pluralitu dejín (príbehov) a rozdelenie moci v absolútne, prostredníctvom pluralizmu božstiev. V monoteizme, ktorého význačným príkladom je biblický a krestáanský monoteizmus, boli staré božstvá potlačené jedným Bohom a tým zrušená polymýtickost', nezostal žiadny priestor pre viaceré ludské dejiny, viaceré príbehy, žiadny priestor pre dejinné indivíduum s jeho vlastnými skúsenostami. Krestanstvo podla Marquarda vytesnilo humánny princíp polyteizmu „z nedele moderného sveta“. Indivíduum ale žije, povstáva z tohto rozdelenia moci, má tu svoj pôvod, vystupuje a vzpiera sa voči monoteizmu. Chápe to tak, že vo svete mnohých bohov zostal pre indivíduum slobodný priestor, nejestvovala služba a podriadenost' iba jednej moci, ale viacerým, čo predpokladá určité „vol'né" pole. Bohovia sú v kolízii, minimum chaosu je podmienkou možnosti vol'by a individuality. Čím viac potencialít si pluralisticky konkuruje, vzájomne sa stretáva a kríži, tým slobodnejšie môže byt́ indivíduum, jeho vol'ba. Človeku prospieva, ked má viac príbehov, presvedčení, tradícií, orientačných bodov. Jednotný výklad skutočnosti nezodpovedá rôznorodým ludským skúsenostiam [Marquard 2015].

Vrátme sa ešte k spomenutej synkretickej tolerancii. Beck uvádza pasáž z knihy sociológa Petra Bergera, ktorý odkazuje na japonského filozofa Nakamu- 
ru, ${ }^{2}$ podla ktorého je Západ zodpovedný za dve vel'ké chyby. „První z nich je monoteismus, podle něhož existuje pouze jeden Bůh, a druhou je aristotelský princip sporu, podle něhož je bud' A, nebo non A. Jak říká, každý inteligentní člověk v Asii ví, že existuje více bohů a že věci mohou být jak $\mathrm{A}$, tak zároveň non A." [Beck 2018: 70]

S monoteistickými náboženstvami je tak späté rozlišovanie pravdy a nepravdy, veriacich a neveriacich; je to zdroj náboženského násilia, ako dokumentujú dejiny. Podla Becka ale krestáanstvo v jeho začiatkoch konkurovalo iným náboženstvám, má pôvod v kontexte pluralizmu Rímskej ríše a nemalo preto monopol na pravdu. Teraz, v druhej moderne sa vraciame spät' na začiatok, kde krestanstvo je znovu jedno náboženstvo medzi mnohými. Jeho vlastnou klúčovou otázkou musí byt', ako sa vyrovnat' s inakostou druhého. „Druhí“ sú príslušníci iných náboženstiev a tiež tí, ktorí sú považovaní za "pohanov“, žijú bez Boha v sekulárnom svete. Toto je dôležitý vztáah a postoj, ktorý by sa mal zmenit', pokial' sa chce Cirkev adaptovat' v druhej moderne [Beck, Willms 2004: 91-116].

Domnievam sa, že zaiste tu nejde iba o výzvu a úlohu pre krestanskú Cirkev. V situácii kozmopolitizácie a globalizácie, ked’ sme podl’a Becka v nedobrovoĺnej konfrontácii s druhým, ktorý je cudzí, vzniká nová potreba hermeneutiky cudzieho. Vidíme, že ústrednou otázkou je otázka vztahu k druhému vôbec. $\mathrm{K}$ blížnemu, druhému a špecificky $\mathrm{k}$ cudziemu. Akoby sa z úzadia ozývalo ono biblické: „A kto je môj blížny?“ Je mojím blížnym aj cudzinec? Je mojím blížnym ten, kto odmieta moje pravdy a hodnoty a snaží sa presadit' vlastné? Jedným z možných riešení je vyhnút sa nedobrovol'nej konfrontácii s druhým, dobrovol'nou vol'bou jej zabránit', odmietnut ju, vystavat' plot alebo múr, povolat' armádu. $\mathrm{V}$ prípade, že to nie je možné, ostáva pre jednotlivcov a náboženské skupiny úloha zachovat' si vlastné, podstatné, nevyhnutné, či považované za pravdivé, bez nutnosti násilného vztáahu $\mathrm{k}$ cudziemu, druhému. Tento postoj nemusí byt́ ilúziou, ale reálnym prejavením tolerantnej, nenásilnej „tváre“ náboženstva. A možno tvrdit podstatného či najhlbšieho jadra náboženstva, pretože násilná "tvár“ je vedomým a slobodným znetvorením najvlastnejšej, pôvodnej, skutočnej „tváre“ náboženstva. Že je možný dokonca „prerod“ či prechod od násilia k nenásiliu, dosvedčujú mnohé príklady.

Okrem vztahu k druhému stojíme aj voči prírode, pred jej „tvárou“, na ktorej rozpoznávame dôsledky a dopad našich mocenských záujmov. Stojíme pred vážnym problémom klimatických zmien a klimatickej katastrofy. A Beck opät' formuluje otázky: „Nevyžaduje snad právě tento úkol kosmopolitní hlas náboženství? Není snad právě ono $s$ to svést lidi rozličné víry na ,společnou' stezku spravedlnosti tváří $\mathrm{v}$ tvář globálním rizikům teroru a válek, klimatické změny a chudoby a také zranění důstojnosti náboženských druhých? Nedokáže snad náboženství v každém př́ípadě přispět tím, že pozvedne svưj hlas na světové veřejnosti a tím pragmaticky obejde a ztlumí svá dogmatická pnutí?“ [Beck 2018: 200]

${ }^{2}$ Hajime Nakamura (1912-1999) bol japonský orientalista, filozof, špecialista na indickú filozofiu. 
Beckovi v tomto smere možno pritakat', dat' za pravdu. Bohužial' zväčša býva apelujúci hlas prichádzajúci zo strany náboženstva neprijatý a nevypočutý. Náboženstvo nie je dôsledne (ak vôbec) prijaté a žité konkrétnym jednotlivcom a jeho hlas nie je akceptovaný ani v spoločnosti. Neraz je vnímané skôr nepriatel'sky. Nie je tiež nahliadané ako "to druhé", "cudzie“, "obtažujúce“ - v domácom prostredí? Neprijatie obsahov a slov náboženstva $\mathrm{v}$ individuálnom živote a v spoločnosti má teda svoje dôsledky. Ak by sa mali realizovat' Beckove uvedené predstavy, muselo by byt náboženstvo najskôr prijaté individuálne a jeho výzvy (apel) v konkrétnej societe. Hovorit' o príčinách tohto neprijatia je už inou, samostatnou témou.

\author{
Martin Vašek \\ Filozofická fakulta \\ Univerzita Konštantína Filozofa v Nitre
}

\title{
Literatúra
}

Bauman, Z. 2014. „Jerusalem Versus Athens Revisited.“ Pp. 71-75 in U. Beck (ed.). Ulrich Beck. Pioneer in Cosmopolitan Sociology and Risk Society. Springer International Publishing.

Beck, U. 2007. Moc a protiváha moci v globálním věku. Nová ekonomie světové politiky. Praha: Sociologické nakladatelství (SLON).

Beck, U., J. Willms. 2004. Conversation with Ulrich Beck. Cambridge: Polity Press.

Beck, U. 2018. Vlastní Bůh. Mírotvorný a násilný potenciál náboženství. Praha: Karolinum.

Habermas, J. 2004. „Die Grenzen zwischen Glauben und Wissen. Zur Wirkungsgeschichte und aktuellen Bedeutung von Kants Religionsphilosophie." Revue de métaphysique et de morale 44 (4): 460-484, https://doi.org/10.3917/rmm.044.0460.

Habermas, J. 2001. Glauben und Wissen. Friedenspreis des Deutschen Buchhandels 2001. Frankfurt am Main: Suhrkamp.

Habermas, J. 2003. „Víra a vědění.“ Pp. 111-112 in J. Habermas. Budoucnost lidské prirozenosti. Na cestě k liberální eugenice? Praha: Filosofia.

Köhler, K. 2009. „Der zweimoderne Gott. Ulrich Beck schreibt über die Friedensfähigkeit der Religionen.“ Literaturkritik.de [online]. Dostupné na: https://literaturkritik.de/id/12832.

Marquard, O. 2015. Abschied vom Prinzipiellen. Stuttgart: Reclam.

Nešpor, Z., D. Lužný. 2007. Sociologie náboženství. Praha: Portál.

Schaeffler, R. 2003. Filosofie náboženství. Praha: Academia.

Tížik, M. 2013. Kritická teória Jürgena Habermasa v sociologickom výskume. Bratislava: Sociologický ústav SAV.

Váně, J. 2010. „Sociologie náboženství v době nejen postmoderní.“ Pp. 64-86 in D. Lužný, D. Václavík. Individualizace náboženství a identita: poznámky k současné sociologii náboženství. Praha: Malvern.

Váně, J. 2013. „Sociologie náboženství: soudobé trendy.“ Pp. 359-382 in J. Šubrt a kolektiv. Soudobá sociologie VI. Oblasti a specializace. Praha: Karolinum.

Vattimo, G., R. Rorty. 2007. Budoucnost náboženství. Praha: Karolinum.

Vido, R. 2011. „Pracovní seminář Česká a slovenská sociologie náboženství po roce 1989 hodnocení, aktuální stav a budoucnost." Sociologický časopis / Czech Sociological Review 47 (5): 1083-1085. 